\title{
The Regulation of Insider Trading in Canada: A Historical Comparative Perspective
}

\author{
Howard Chitimira \\ Lecturer, Faculty of Law, North-West University \\ E-mail:Howard.Chitimira@nwu.ac.za, tafarachitimira@gmail.com
}

\section{Doi:10.5901/mjss.2014.v5n4p144}

\section{Abstract}

A well developed anti-insider trading regulatory framework is in place in Canada. This Canadian anti-insider trading regulatory framework is actually characterised by its relatively stringent but effective statutory prohibition on insider trading. It is against this background that an overview historical comparative analysis of the relevant Canadian and South African insider trading laws will be carried out in this article to explore their similarities and differences. This is primarily done to expose certain flaws that are embedded in such laws and to recommend, where necessary, possible solutions that could be utilised by policy makers to enhance the combating of insider trading in South Africa. To this end, any meaningful lessons that can be learnt and innovations that can be recommended for adoption in South Africa will be identified and briefly discussed. Furthermore, in addition to the comparative analysis that is done under each sub-heading, the article also provides an overall overview evaluation of the anti-insider trading regulatory and enforcement framework in Canada in order to recommend possible measures that could be employed in South Africa to effectively combat insider trading.

Keywords: regulatory framework, Canada, insider trading, financial markets, enforcement.

\section{Introduction}

A relatively well developed anti-insider trading regulatory framework is in place in Canada. This Canadian anti-insider trading regulatory framework was also regarded by one commentator as one of the most effective and adequate regulatory framework to be found in recent years, (see Osode "Regulatory Theory, Private Interests and the Rationality of Insider Trading Regulation in the United States and Canada" 1998 Journal of South African Law 427 437). It is characterised by its relatively stringent but effective statutory prohibitions on insider trading, (see Osode "The Regulation of Insider Trading in Canada: A Critical Appraisal" 1999 Anglo- American Law Review 166 166-196). It is against this background that an overview historical comparative analysis of the relevant Canadian and South African insider trading laws will be carried out in this article to explore their similarities and differences. This is primarily done to expose certain flaws that are embedded in such laws and to recommend, where necessary, possible solutions that could be utilised by policy makers to enhance the combating of insider trading and other related market abuse practices in South Africa. To this end, any meaningful lessons that can be learnt and innovations that can be recommended for adoption in South Africa will be identified and briefly discussed, (however, only relevant Canadian cases and provisions will be analysed and contrasted with those in South Africa). Furthermore, in addition to the comparative analysis that is done under each sub-heading, the article also provides an overall overview evaluation of the anti-insider trading regulatory and enforcement framework in Canada in order to recommend possible measures that could be employed in South Africa to effectively combat insider trading. However, the discussion on the Canadian insider trading prohibition is predominantly focused on the Ontario Securities Act of 1990 as amended, (therefore, a critical examination of all the provincial insider trading legislation and cases in Canada is beyond the scope of this article. In other words, the focus is on selected legislative instruments and their basic application).

\section{Historical Overview of Insider Trading Regulation in Canada}

The statutory regulation of insider trading is still predominantly a provincial matter in Canada despite several attempts to enact a single uniform federal statute, (see Welling Corporate Law in Canada: The Governing Principles (1991) 363; Welling Corporate Law in Canada: The Governing Principles (2006) 1-728). The first statute on insider trading in Canada was the Ontario Securities Act of 1966 (Statutes of Ontario 1966 c 142, hereinafter referred to as the Ontario Securities Act), which was passed pursuant to the adoption of the Report of the Attorney General's Committee on Securities 
Legislation in Ontario on 11 March 1965. (This report is hereinafter referred to as the Kimber Report; see pars 1.06; 1.11 \& 7.15 of the Kimber Report and ss 108-117 of the Ontario Securities Act which contained the first insider trading prohibition in Canada). Prior to this date, insider trading was not statutorily regulated in Canada. This Act was, however, only applicable to insider trading activity in the securities of "reporting issuers", (a reporting issuer is a corporation or a company whose securities are traded on a stock exchange or other market place). This led to various subsequent legislative reviews of the Ontario Securities Act and similar statutes in other provinces in an attempt to have more stringent and adequate provisions against insider trading.

The insider trading prohibition was for instance also contained in the Canada Corporations Act of 1970, (hereinafter referred to as the Canada Corporations Act 1970). This Act was, inter alia, aimed at preserving the integrity of federal companies by protecting their shareholders against insider trading, (see Multiple Access Ltd v McCutcheon and others (1982) 138 DLR (3d) 18 (SCC)). Moreover, the Canada Corporations Act 1970 prohibited insiders or other persons who held positions of trust or otherwise from trading in the securities of a company if they were privy to pricesensitive information relating to such securities which was not yet available to all its shareholders.

A subsequent review of the Canada Corporations Act 1970 resulted in the enactment of the Canada Business Corporations Act of 1975 (Canada c 33, hereinafter referred to as the Canada Business Corporations Act 1975; see generally Welling (1991) 365; Welling (2006) 1-728 \& Smith "Insider Trading" <http://www.parl.gc.ca> (accessed 22-122012). This Act prohibited insider trading in a "distributing corporation", which was defined to include a corporation that is a reporting issuer unless it is subject to an exemption from the relevant legislation; or has filed a prospectus in relation to the public distribution of its shares, if such shares and/or their price remains outstanding and they are held by more than one person; or has securities that are listed and traded on a stock exchange in or outside Canada. Furthermore, the Canada Business Corporations Act 1975 prohibited insiders from selling shares that they do not own or have a right to own, and from buying or selling a call option or put option in respect of a share of the distributing corporation in relation to which they are insiders. (See ss 126(1) \& 130 read with s 131). Similar provisions were retained with minor changes in the Canada Business Corporations Act of 1985 (RSC, c.C-44, hereinafter referred to as the Canada Business Corporations Act 1985; see ss 126; 130 and 131).

In an attempt to complement and revive the original insider trading provisions which were contemplated in the Ontario Securities Act, the Ontario Business Corporations Act of 1982 (SO 1982 c 4, hereinafter referred to as the Ontario Business Corporations Act; see generally Anonymous Ontario Securities Legislation (1977) 46-47) was enacted. This Act broadened the definition of insiders to include not only "senior officers", but all the employees of any corporation or company. However, it dealt mainly with the liability of insiders of corporations or companies that do not offer securities to the public, (see Welling (1991) 364; Welling (2006) 1-728). This eventually led to yet another legislative review which resulted in the enactment of the Ontario Securities Act of 1990 as amended. (Revised Statutes of Ontario 1990 c S 5, hereinafter referred to as the Ontario Securities Act 1990; see Macintosh \& Christopher Essentials of Canadian Law: Securities Law (2002) 231). The Ontario Securities Act 1990 expanded the reporting obligations of all insiders (s 1(1)) of the reporting issuers in terms of section 107. This was meant to deter insiders from profiting unfairly from their prior knowledge of any unpublished confidential inside information relating to a company, such as an impending take-over or other acquisition.

In 2003 the Canadian Securities Administrators (the CSA) and the federal government introduced a Uniform Securities Law Project (the USL) and a Bill C-46 respectively in an attempt to improve the overall regulation of insider trading in all the provinces of Canada and address possible cross-border insider trading challenges. (See the Insider Trading Task Force Report (the ITTF Report) "Illegal Insider Trading in Canada: Recommendations on Prevention, Detection and Deterrence" (2003) 35 <http://www.regulationservices.com/en/pdf/1TTFReport_20031112.pdf> (accessed 26-05-2013). The USL Project was mainly aimed at providing a national framework for securities regulation by the harmonisation of insider reporting obligations. Likewise, Bill C-46 proposed the introduction of new Criminal Code of Canada (2004, c.3, S. 5, hereinafter referred to as the Criminal Code) offences for illegal insider trading and tipping. Eventually, Bill C-13 was introduced in March 2004. This Bill introduced the first specific Criminal Code offences in relation to insider trading and other related practices. It also made it an offence to threaten or retaliate against employees who reveal any insider trading or related activities (whistle-blowing).

Unlike the Canadian position, the statutory regulation of insider trading was only introduced by the relevant provisions of the Companies Act 61 of 1973, (hereinafter referred to as the Companies Act; see s 224 \& ss 229 to 233) in South Africa. However, these provisions were flawed in many respects (see the Van Wyk de Vries Commission of Inquiry into the Companies Act of 1973; Bhana "Take-Over Announcements and Insider Trading Activity on the Johannesburg Stock Exchange" 1987 South African Journal of Business Management 198-208; Botha "Control of Insider Trading in 
South Africa: A Comparative Analysis" 1991 SA Merc LJ 1-18; Botha "Increased Maximum Fine for Insider Trading: A Realistic and Effective Deterrent?" 1990 SALJ 504-508). For instance, insider trading was merely treated as a criminal offence which could be committed by a director, officer or employee of the company or a person in accordance with whose instructions, any director was accustomed to act. As a result, the Companies Amendment Act 78 of 1989, (hereinafter referred to as the Companies Amendment Act; see s 6; Memorandum on the Objects of the Companies Second Amendment Bill of 1989 B 99-89 (GA)) and the Second Companies Amendment Act 69 of 1990, (hereinafter referred to as the Second Companies Amendment Act; see the revised S 440F; Memorandum on the Objects of the Companies Second Amendment Bill of 1990 B 119-90 (GA); Explanatory Memorandum to the Objects of the Companies Second Amendment Bill of 1990 B 119-90 (GA)) were introduced to improve the regulation of insider trading in South Africa. Nonetheless, the insider trading ban in the Companies Act (including all its amendments prior to 2004) was still inadequate (Henning \& Du Toit "The Regulation of False Trading, Market Manipulation and Insider Trading" 2000 Journal for Juridical Science 155 155-165; Osode "The Regulation of Insider Trading in South Africa: A Public Choice Perspective" 1999 African Journal of International and Comparative Law 688 688-708; Van der Lingen "Tougher Legislation to Combat Insider Trading" 1997 FSB Bulletin 10;Van Zyl "Aspekte van Beleggersbeskerming in die SuidAfrikaanse Reg" 1992 Transactions of the Center for Business Law 231-357). This led to the enactment of the Insider Trading Act 135 of 1998, (hereinafter referred to as the Insider Trading Act; see ss 2 \& 6) but still its prohibition had some shortcomings. (Osode "The new South African Insider Trading Act: Sound law reform or legislative overkill?" 2000 Journal of African Law 239 239; Van Deventer "New watchdog for insider trading" 1999 FSB Bulletin 2 3; the King Task Group into Insider Trading Legislation Minority Report on Insider Trading 1997 paragraph 3.4 as summarised in Beuthin \& Luiz Beuthin's Basic Company Law (2000) 235-238; also see generally Chitimira The Regulation of Insider Trading in South Africa: A Roadmap for an Effective, Competitive and Adequate Regulatory Statutory Framework (LLM dissertation, University of Fort Hare, 2008) 41-72; Luiz "Prohibition Against Trading on Inside Information-The Saga Continues" 1990 SA Merc LJ 328 328-332; Luiz "Insider Trading Regulation - If at First You Don't Succeed..." 1999 SA Merc LJ 136 136151; Jooste "Insider Trading: A New Clamp-Down" 1991 BML 248 248-250; Jooste "Insider Dealing in South Africa-The Criminal Aspects" 1990 De Ratione 21 21-28). Subsequently, the Securities Services Act 36 of 2004, (hereinafter referred to as the Securities Services Act; see ss 73 \& 77) was enacted. This Act, however, retained some flaws such as inadequate penalties and inconsistent enforcement approaches that were initially contained in the Insider Trading Act. (Jooste "A critique of the insider trading provisions of the 2004 Securities Services Act" 2006 SALJ 437 441-460; Chanetsa "Insider Trading is Notoriously Hard to Prosecute" Business Report 26 April 2004; Pretorius and Another $v$ Natal South Sea Investment Trust 19653 SA 410 (W), were the courts failed to convict the suspected insider trading offenders; Ojah, Muhanji \& Myburg "Market Reaction and Equity Market Efficiency: A Survey of the Insider Trading Law in South Africa" 2008 The African Finance Journal 1-28; Van Deventer "Anti-Market Abuse Legislation in South Africa" (10-06-2008) 1-5 <http://www.fsb.co.za/public/marketabuse/FSBReport.pdf> (accessed 05-08-2013) \& Myburgh \& Davis "The Impact of South Africa's Insider Trading Regime: A Report for the Financial Services Board" (25-03-2004) 8-33 $<$ http://www.genesis-analytics.com/public/FSBReport.pdf> (accessed 09-07-2013). Moreover, notwithstanding the fact that the Companies Act was recently repealed by the Companies Act 71 of 2008, (hereinafter referred to as the Companies Act 2008), the Companies Act 2008 does not expressly prohibit insider trading.

Eventually, the Financial Markets Bill B-2011, (see clauses 82 \& 86) and the Financial Markets Bill B12-2012 were introduced, (see clauses $80 \& 84$; the term "clause" is employed to refer to the provisions of these Bills). Thereafter, the Financial Markets Act 19 of 2012, (hereinafter referred to as the Financial Markets Act; see ss 78 \& 82) came into effect on 03 June 2013 in another bid to, inter alia, enhance the combating of insider trading in South Africa.

Notably, the provincial regulation of insider trading which increased awareness and contributed immensely towards the timeous prosecution of insider trading cases in Canada (see Thompson "A Global Comparison of Insider Trading Regulations" 2013 International Journal of Accounting and Financial Reporting 1 8-9 \& 15; Re Cartaway Resources Corporation [2004] 1 SCR 672; Re Costello [2004] OJ 2972; Re Donald (2012) 35 OSCB 7383, where Donald was found not guilty of insider trading but was found guilty of acting contrary to the public interest and affecting the capital markets confidence and ordered to pay investigation and litigation costs of $\$ 150000.00 ; R e$ Donnini [2003] OJ No 3541; Re Donnini (2003) 177 OAC 59 (Div Ct); Re Donnini (2003) 37 BLR (3d) 46; Re Donnini (2002) 25 OSCB 4697, Re Donnini (2002) 25 OSCB 6225; Re Donnini (28 January 2005) Doc. C41330 (Ont.C.A.), where Donnini was found guilty of insider trading and his registration as a securities trader was suspended for 15 years and was ordered to pay investigation and litigation costs of $\$ 186052.00$ ) is not employed in South Africa. Accordingly, notwithstanding the existence of a central companies registry and a single licensed stock exchange in South Africa, policy makers could, perhaps consider enacting, (in addition to the national insider trading legislation), some provincial anti-insider trading by- 
laws to enhance awareness and the timeous prevention of insider trading activities in the South African companies and financial markets.

\subsection{The Scope and Meaning of Insider Trading}

Seemingly, Canada has also followed the American approach by electing not to statutorily and expressly define the concept of insider trading. (This American approach has general anti-fraud provisions in terms of the Securities Services Act 1934, which only define certain concepts in the applicable "rules" under that Act). Only a few terms such as "insider", "reporting issuer", "special relationship" and "issuer" are comprehensively defined. Other important terms like "tippees", "inside information" and "illegal insider trading" are not expressly defined. Moreover, insider trading is generally regarded as a practice that involves the buying or selling of securities under circumstances where one of the parties is in possession of undisclosed material information about the securities or about the issuer, or where that information has been tipped off to one of the parties or where securities are being traded by the person who was tipped. (See the ITTF Report 1; Macintosh \& Christopher 237).

South Africa seems to be following this American approach as well. For instance, the term "insider trading" was not expressly defined in the Companies Act ("including all its amendments prior to 2004"; see s 224; ss 229 to 233; ss 6 \& 440F) and the Insider Trading Act (see ss 2 \& 6). Moreover, although some of the elements of the insider trading offence were merely stated, the concept of "insider trading" was also not statutorily and expressly defined under the Securities Services Act and the Financial Markets Act. (See ss $72 \& 73$ of the Securities Services Act and ss $77 \& 78$ of the Financial Markets Act). Additionally, key terms such as "material effect", "specific" or "precise" and "tippees" were not adequately defined in the Securities Services Act and the Financial Markets Act. This failure, on the part of the policy makers, to provide adequate definitions of these and other terms could have contributed to the inconsistent enforcement of the insider trading prohibition in South Africa to date. (The words "specific" or "precise" should have been statutorily defined differently from their ordinary dictionary meaning to address potential interpretation problems surrounding these words as regards to when "the exact time" can it be said the inside information is "precise" or "specific"). Consequently, it remains to be seen whether the recently enacted Financial Markets Act's anti-insider trading regulatory framework will be consistently enforced to combat insider trading in South Africa.

\subsection{The Prohibition on Insider Trading}

The provisions of the Ontario Securities Act 1990 prohibits any person in a "special relationship" (s 76(5) read with s 1(1)) with a reporting issuer and who has knowledge of an undisclosed "material fact" or "material change" of relevant circumstances relating to securities from disclosing it to others or trading on the basis of such information to the detriment of others. (The terms "material fact" or "material change" were defined to constitute a change in business, operations or capital of an issuer or a fact that can reasonably be expected to have a significant effect on the market price or value of the securities of the issuer; see National Instrument 51-102 on "Continuous Disclosure Requirements" 27 OSCB 3443).

Notably, the insider trading prohibition stipulated in section 76 applies to a much wider range of persons and companies than is covered by the definition of 'insider' under section 1(1) of the Ontario Securities Act 1990. (See Macintosh \& Christopher 238). Therefore, the most important definition in section 76 is probably not that of an "insider" but rather that of a "special relationship person". The term "special relationship" was specifically defined in terms of section 76(5) to mean:

(a) insiders, affiliates (s 1 par 1.1(2)) and associates (s 1(1)) of a reporting issuer and others engaging in various transactions (such transactions include first, the making of a takeover bid or secondly, entry into a business combination such as a reorganisation, or a merger or thirdly, acquisition of a substantial portion of the issuer's property) with respect to such issuers (s 76(5)(a)(i), (ii) and (iii));

(b) persons or companies engaged in or proposing to engage in any business or professional activity with or on behalf of a person that is proposing to engage in similar transactions with the reporting issuer (s 76(5)(b));

(c) directors, officers or employees of the reporting issuer and others proposing to engage in similar transactions as contemplated in sections 76(5)(a)(ii) or (iii) and 76(5)(b) (see s 76(5)(c));

(d) a person or company that learned of the material fact or change with respect to the reporting issuer, while the person or company was a person or company described in subsections (a),(b) or (c) above (see s 76(5)(d)); and

(e) a person or company that learns of a material fact or change with respect to the reporting issuer from any 
other person or company described in this section who knows or ought reasonably to have known that the other person or company is in such a relationship (s 76(5)(e)).

It is clear that this definition covers not only those persons who work within the reporting issuer, but also others who work within different companies or proposing to enter into a major business transaction or arrangement such as a takeover of the issuer's shares.

Moreover, other related practices such as tipping are also prohibited (Johnston \& Rockwell Canadian Securities Regulation (2006) 269). For instance, unlawful disclosure to another of unpublished material information relating to the reporting issuer's securities, whether by that issuer, a special relationship person or any other person in possession of such information, is prohibited in terms of section 76(2) and (3). (See Condon et al Securities Law in Canada-Cases and Commentary (2006) 433-477). In order to reduce the risk of illicit insider trading, all persons referred to in section 76 of the Ontario Securities Act 1990 are prohibited from speculative trading in the securities of any corporation or company.

In South Africa, the Companies Act as amended (s 224; ss 229 to 233; ss 6 \& 440F) prohibited insider trading by precluding directors, officers, employees and their tippees from dealing in a company's shares before the "inside information" relating to such shares was made public. However, this prohibition was only limited to listed shares and/or securities (s 233).

On the other hand, actual dealing in securities or financial instruments for making a profit or avoiding a loss for oneself as well as for any other person was prohibited under the Insider Trading Act (ss 2(1)(a) read with s 6). Moreover, improper disclosure of non-public price-sensitive information (s 2(2) read with s 6 ) and encouraging or discouraging (tipping) (s 2(1)(b) read with s 6) another person to deal or from dealing in securities or financial instruments were further prohibited under the Insider Trading Act. Nonetheless, this prohibition did not apply to juristic persons and a natural person could only be guilty of the offence if he was fully aware that he was in possession of inside information and failed to prove any of the defences that were provided (s 4(2)). Due this and other flaws such as inconsistent enforcement and inadequate penalties, the Insider Trading Act was repealed by the Securities Services Act which, despite outlawing same insider trading conduct like its predecessor, extended the insider trading prohibition to both juristic and natural persons (see ss 73 \& 77; notably, the aforesaid conduct namely, the improper disclosure of non-public price-sensitive information; encouraging or discouraging another person to deal or from dealing in securities and actual dealing in securities for making a profit or avoiding a loss for oneself or for another person is also prohibited in the Financial Markets Act (ss 78 \& 82). However, the Securities Services Act retained some flaws that were previously contained in the Insider Trading Act. For instance, its insider trading prohibition was still mainly applicable to securities listed on a regulated market (this is also the position in Canada) and rigidly based on the requirement that the offenders could only be guilty of insider trading offences if they were fully aware that they were in possession of non-public inside information when they committed such offences (see ss $73 \& 77$; notably, the requirement of knowledge is flexibly enforced in Canada, having regard to several available insider trading defences and exemptions). Conspicuously, these flaws contained in the Securities Services Act have remained unresolved in the in the Financial Markets Act (ss 78 \& 82).

\subsection{Reliance on both Civil and Criminal Sanctions}

Civil as well as criminal sanctions are used to curb both insider trading and tipping in Canada. The criminal sanction will be discussed first, and then the civil remedy and lastly, a comparative analysis will be made with respect to similar sanctions in South Africa.

Any "special relationship" persons who violate the provisions of section 76, whether through tipping or engaging in unlawful insider trading will be liable for a criminal offence. (See ss 122(1)(c) \& 76(1), (2) \& (3)). If convicted, such persons may be sentenced to pay a fine equal to the amount of the profit made or loss avoided but up to a maximum of $\$ 1$ million, or to imprisonment for two years or both (s 122(1)). These penalties were later increased and offenders could be liable to a minimum fine of up to $\$ 5$ million or imprisonment for a period not more than five years less one day or both (s 122(1)). Such persons may further be ordered to pay a minimum fine equal to the profit made or loss avoided and an additional maximum penal fine equal to the greater of $\$ 5$ million, and/or the amount equal to three times the profit made or loss avoided. (See s 122(4) \& (5); $R$ v Harper (2000) OJ 3664 where the accused was convicted on two counts of insider trading in terms of $s$ 122(1)(c)). Furthermore, with respect to tipping, it is not required that the tippees should have traded on the premise of the confidential inside information they received from special relationship persons, before any criminal liability can be imputed on them.

Notably, under the Canada Business Corporations Act 1985 persons guilty of short selling and/or insider trading were liable on summary conviction to a fine not exceeding the greater of $\$ 1$ million and three times the profit made, or 
imprisonment for a term not exceeding six months or to both (s 130(4)). Furthermore, Bill C-13 of 2004 introduced the first specific Criminal Code sanctions for insider trading and tipping of a maximum imprisonment term of up to ten years (s 382.1(1)) and five years (s 382.1(2)) respectively. Both insider trading and tipping are treated as indictable offences under the Criminal Code. Canada has relatively obtained some success in prosecuting criminal cases of insider trading and other related practices. For example, prosecutions and settlements were successfully obtained in thirteen cases of insider trading and about \$1.9 million fines and fees were recovered from the offenders in 2010. (See Thompson 9). In the same year, Cornblum and Grmovsek were found guilty of insider trading in Canada and the United States of America. Eventually, Grmovsek was sentenced to disgorge the illicit profits gained of about $\$ 8.5$ million with a waiver of nearly $\$ 1.5$ million in the United States of America. (See Emily Cole "Canada's first Criminal Conviction for Illegal Insider Trading" Criminal Law, Regulation and Enforcement Newsletter February 2010 1-2). Grmovsek was further sentenced to 39 months imprisonment and ordered to pay the Ontario Securities Commission (the OSC) a total fine of $\$ 1.03$ million, as well as $\$ 283000.00$ to the Attorney-General of Ontario and $\$ 250000.00$ investigation costs to the OSC in Canada. (See Cole 2; Thompson 9).

A civil remedy is also available to all the persons who fall victims to unlawful insider trading (s 131(4) \& (5) of the Canada Business Corporations Act 1985) and tipping (s 131(6) \& (7) of the Canada Business Corporations Act 1985; see further s 134(1) of the Ontario Securities Act 1990). For instance, any special relationship person who trades while in possession of unpublished price-sensitive information is liable to compensate all the affected persons (plaintiffs) for any damages caused by such trading. (See Doman v British Columbia (Superintendent of Brokers) (1998) BCJ 2378 (CA). This civil remedy is available to four classes of plaintiffs:

a) first, those who are the innocent counterparties to unlawful insider trading with insiders;

b) secondly, those who are the innocent counterparties to insider trading with tippees;

c) thirdly, to mutual funds or the clients of portfolio managers or of registered dealers, against someone who had access to unpublished confidential information relating to the investment program of those funds, managers or dealers and who benefits by trading on the basis of such information (s 134(3) of the Ontario Securities Act 1990); and

d) lastly, reporting issuers whose insiders, affiliates, or associates have gained by trading with knowledge of undisclosed material information or have communicated such information to others (s 134(4) of the Ontario Securities Act 1990; see further Williamson Securities Regulation in Canada (1960) 347-352).

The basis for liability in terms of section 134 differs, depending upon whether the plaintiff is an innocent party to the unlawful trade or is the reporting issuer to which the undisclosed information relates. Innocent counterparties to unlawful insider trading are entitled to recover from the defendant any damages they may have suffered as a result of such trading. On the other hand, in cases of actions brought by a reporting issuer, liability of insiders, associates or affiliates of such an issuer is measured by the extent of any gain they have realised as a result of insider trading. Furthermore, insiders who commits insider trading and/or tipping will be directly liable to pay civil compensatory damages to the affected corporation and individuals under the Canada Business Corporations Act 1985 (s 131(4); (5); (6) \& (7)).

South Africa also employs criminal and civil sanctions to curb insider trading. However, insider trading was mainly treated as a criminal offence which carried inadequate penalties of R500 000 fine or imprisonment for a period of ten years, or both under the Companies Act as amended prior to 2004 (s 224; ss 229 to 233; ss 6 \& 440F). Eventually, insider trading attracted both criminal (s 2) and civil liability (s 6) under the Insider Trading Act and offenders were liable to pay the Financial Services Board (the FSB) a fine not exceeding R2 million, or imprisonment for a period not exceeding ten years, or both such fine and such imprisonment (s 5; nevertheless, these penalties were inadequate for deterrence purposes). Consequently, insider trading was treated as a civil, criminal and administrative offence under the Securities Services Act and recently, in the Financial Markets Act. However, offenders were still liable to relatively insufficient penalties of a fine not exceeding R50 million, or imprisonment for a period not exceeding ten years or both such fine and imprisonment under the Securities Services Act (s 115(a); Cassim "An Analysis of Market Manipulation under the Securities Services Act 36 of 2004 (Part 2)" 2008 SA Merc LJ 177 191-195). Ironically, the same penalties were retained in the Financial Markets Act (s 109(a)). Moreover, unlike the position in Canada, the defendant's civil liability in terms of the Financial Markets Act is not contingent upon whether the affected person is an innocent counterparty or not (see s 82). Perhaps, in this regard, such a distinction should have been drawn in the Financial Markets Act to enhance the enforcement of the civil remedy in South Africa. 


\subsection{Available Defences and Exemptions}

A number of defences and exemptions are available for insiders or any other person alleged to have contravened insider trading provisions in Canada. For instance, under the Ontario Securities Act 1990, any offenders accused of contravening section 76 may avoid liability if they are able to rely on the defences or exemptions summarised below:

a) with respect to tipping, any tippee who knowingly trades on the basis of material confidential information before it is "generally disclosed" (this term is not defined under the Ontario Securities Act 1990) may escape liability if he proves that he did not know or ought not reasonably to have known that the tipper was a person, or a company in a special relationship with the reporting issuer. (See s 76(4) read with subs (5)(e); also see Green v Charterhouse Group Canada Ltd (1976) 12 OR (2d) 280 (CA) 302-303, where it was held that limited disclosure of relevant information does not suffice for the purposes of this defence and In Re Harold P Connor (1976) OSC Bulletin 149 174, for further discussion on the circumstances suggested by the OSC to determine whether the confidential information is generally disclosed). Apparently, the mere issuing of a press release without actual and timeous disclosure of material facts to the public is insufficient for the purposes of this defence;

b) another defence in terms of section 76(4) is only available to companies or individuals that traded on the basis of the undisclosed confidential information which they reasonably believed that it had already been publicly disclosed and/or was known or ought reasonably to have been known to the affected person (Johnston \& Rockwell 274);

c) the courts have also recognised a "reasonable mistake of fact" defence in some instances where the accused person mistakenly traded on price-sensitive information before it had been generally disclosed. (See Lewis $v$ Fingold (1999) 22 OSCB 2811, where the accused was acquitted after he successfully raised the defence of mistake and also see Rider Insider Trading (1983) 283-301);

d) a Chinese wall defence is also available to companies that have some measures to prevent the abuse of nonpublic inside information between their different departments. (See the OSC Policy 33-601 "Guidelines for Policies and Procedures Concerning Inside Information" 30 January 1998, hereinafter referred to as "the OSC Policy 33-601"; also see Transpacific Sales Ltd (Trustee for) v Sprott Securities Ltd (2001) OJ 597(Sup Ct); S 175(1) \& (3) \& Johnston \& Rockwell 276);

e) liability for violating sections 76 and 134 can still be avoided in terms of the exemptions provided under section 175 and the Ontario Securities Act 1990 Regulations, for instance, where accused persons who participated in, or who advised on a particular trading decision did not have actual knowledge of the undisclosed price-sensitive information (s 175(1) \& (3); reg 1015 of Ontario Securities Act 1990 Regulations \& Johnston \& Rockwell 276) or where the purchase or sale of the securities occurred pursuant to a pre-existing agreement, plan or commitment (s 175(2); reg 1015 of Ontario Securities Act 1990 Regulations). These exemptions are also available to a person who, or a company which, was acting as an agent for a third party pursuant to a specific order (s 175(2)).

f) accused persons could also be exempted from insider trading and tipping liability under the Canada Business Corporations Act 1985 if they prove that they reasonably believed that the confidential information in question had already been publicly disclosed (s 131(4)(a) \& subs (6)(a)), or was known or ought reasonably to have been known to the affected person (s 131(4)(b) \& subs (6)(b)) and/or that they acted in the normal course of their business or profession (s 131(4)(c) \& subs (6)(c) \& (d); see further the National Policy 51-201 "Disclosure Standards" 25 OSCB 4497; s 3.3 \& Johnston \& Rockwell 277); and

g) accused persons could further be exempted from tipping liability under the Criminal Code if they prove that they acted in the normal course of their business or profession (s 382.1(2)).

On the other hand, it appears that no sufficient defences for insider trading offences were expressly provided under the Companies Act as amended prior to 2004 in South Africa (see s 224; ss 229 to 233; ss 6 \& 440F). However, under the Insider Trading Act, the offenders could escape liability if they prove on a balance of probabilities that:

a) they were acting on specific instructions from a client unless it was actually that same client who had disclosed the inside information to them (s 4(1)(a); however, professional negligence on the part of the client or accused persons would exclude reliance on this defence); or

b) they would have acted in the same manner even if the inside information was not disclosed to them (s $4(1)(b))$; or

c) they were acting on behalf of a public sector body in pursuit of a monetary policy, policies in respect of 
exchange rates, management of a public debt or foreign exchange reserves (s 4(1)(c)); or

d) their dealing was in pursuit of the completion or implementation of an affected transaction as defined in section 440A of the Companies Act (s 4(1)(d)); or

e) they reasonably believed that no person would deal in the securities or financial instruments as a result of their disclosure of inside information (s 4(2)(a)); or that such disclosure was in the proper performance of their office, employment or profession and at the same time they disclosed that such information was essential inside information (s $4(2)(b))$.

Nonetheless, these defences were not exhaustive (s 4(3) and were still insufficient. For instance, other additional defences such as Chinese walls were not considered. Ironically, similar defences and flaws were re-introduced in the Securities Services Act (s 73(1)(b); subss (2)(b); (3)(b)). Moreover, relatively inadequate and few new defences were introduced under the Financial Markets Act (s 78(1)(b); subss (2)(b); (3)(b); (4)(b)). For example, no defence is expressly extended to the persons accused of encouraging or discouraging others from dealing in certain listed securities under the Financial Markets Act (s 78(5)). Additionally, no exemptions or alternative defences such as Chinese walls are expressly provided for companies and persons facing civil liability charges for insider trading in the Financial Markets Act (s 82). Thus, in contrast to the position in Canada, it seems that the defences currently stipulated in the Financial Markets Act are mainly restricted to instances involving criminal cases of insider trading (see s 78 read with s 82).

\subsection{The Role of the Regulatory bodies and other Role-Players}

\subsubsection{The Role of the Intermarket Surveillance Group}

The Intermarket Surveillance Group (the ISG) was established to provide an inter-market anti-insider trading regulatory framework for the sharing of information and coordination of regulatory efforts among securities and commodities markets and market regulators in North America, Europe and Asia. (See the ITTF Report 33). This regulatory framework is responsible for combating inter-market trading abuses and developing best practices. Canada is a member of the ISG and its equities and derivatives markets can, therefore, trade with similar markets around the world. Moreover, the technological surveillance department of the ISG enables the Canadian equities and derivatives markets to effectively detect any patterns of cross-border insider trading activities in similar markets globally. The ISG further implemented a database that assists member market regulators to share relevant information and to investigate inter-market insider trading. However, it is not clear whether Canada had successfully utilised this database to curb insider trading.

Contrary to this ISG initiative to combat cross-border insider trading and related activities and the participation of Canada therein, it appears that neither the Johannesburg Stock Exchange Limited (the JSE) nor the FSB is a member of the ISG. In this regard, it is hoped that these South African regulatory bodies will also participate in international initiatives such as the ISG in order to co-operate and exchange relevant information with similar bodies in other jurisdictions so as to enhance the combating of cross-border insider trading activities.

\subsubsection{The Role of the Insider Trading Task Force}

The Insider Trading Task Force (the ITTF) was established in September 2002 and commissioned by the CSA with the objective of evaluating how best to curb illegal insider trading in the Canadian securities and capital markets (see the ITTF Report 37-38; Thompson 9). This followed concerns by some securities regulators that there was a public perception that unlawful insider trading practices were prevalent and increasing in the Canadian securities and capital markets, at a time when few successful enforcement actions against such practices were obtained in the courts. The regulatory authorities that expressed concerns were the Ontario, British Columbia and Alberta Commissions, Commission des valeurs mobilieres du Quebec, the Investment Dealers Association of Canada, the Bourse de Montreal Incorporated and the Market Regulation Services Incorporated.

Therefore, the role of the ITTF is to examine the regulation of illicit insider trading in the Canadian securities and capital markets in order to devise suitable methods of increasing the capacity of regulators to detect insider trading activity when it occurs in offshore and nominee accounts, by coordinating the regulation of equities and their derivatives. For instance, 15 of about 289 insider trading cases investigated in Canada between 2001 and 2002 involved offshore accounts. (see Anonymous "Insider trading-What's the problem?" <http://www.cbc.ca/news/background/crime linsider_trading.htm> (accessed 21-12-2012)). The ITTF is also empowered to promulgate best practices for dealers, issuers and service providers to limit the leakage of inside information. Furthermore, the ITTF is responsible for ensuring 
that the provisions of insider trading statutes are adequate, and that there is better coordination among regulatory authorities as well as improved enforcement mechanisms. For purposes of adequacy and effectiveness, the ITTF focuses on three main policy goals namely, deterrence, detection and prevention. It is submitted that the ITTF has contributed immensely towards the effectiveness of the Canadian insider trading regulatory framework (see the ITTF Report 1).

In South Africa a similar task force called "The King Task Group into the Insider Trading Legislation" (the King Task Group) was appointed by the Ministry of Finance in 1995 and it recommended further reforms of insider trading and other related laws. (The King Task Group published its first draft report on 15 May 1997 and the final report on 21 October 1997). However, unlike the position in Canada, the King Task Group was not established the by regulators such as the JSE and the FSB and its mandate was only restricted to examine insider trading regulation prior to 1998.

\subsubsection{The Role of the Courts}

In Canada, both the High and Supreme Courts are empowered to prosecute insider trading cases as stipulated in the provincial securities statutes and other statutes such as the Canada Business Corporations Act 1985. However, under the provincial statutes, the compliance orders that the courts may impose, differ from one province to the other. Consequently, the disgorgement orders, civil penalties, monetary fines and imprisonment terms imposed by the courts in Alberta may be different from those imposed by the courts in Ontario. Moreover, in quasi-criminal proceedings, relevant courts in various provinces may impose fines ranging from $\$ 1$ million to $\$ 5$ million, or the payment of a multiple of the profits made and imprisonment sentences for periods that range between three, five and ten years. (See the ITTF Report 41). Although the sanctions that may be imposed by courts are not uniform, it is submitted that these courts still play a substantial role in the curbing of illegal insider trading and related practices in Canada. (See the ITTF Report 41). Moreover, a number of successful convictions and settlements that have been obtained in insider trading cases to date could also be indicative of the effectiveness of the courts. (See Green v Charterhouse Group Canada Ltd 302-303; Lewis v Fingold 2811; In the Matter of MCJC Holdings Inc and Michael Cowpland (2002) 25 OSCB 1133). With respect to civil cases, clear guidelines are provided in terms of the Ontario Securities Act 1990 by which the courts may determine the compensatory damages for prejudiced persons (s 134(6); also see s 131(8) of the Canada Business Corporations Act 1985). It is further submitted that the courts have a discretion where necessary, to supplement the guidelines in section 134(6) with additional, adequate and appropriate measures as the circumstances of each case may dictate. This has enabled the courts to successfully obtain many settlements in civil cases.

In South Africa, both the Securities Services Act (s 82(9) read with s 79) and the Financial Markets Act (s 84(10) read with s 77) provided that the prosecution of all the criminal cases of market abuse rests mainly with the Director of Public Prosecutions and not with the FSB. Even so, the Director of Public Prosecutions may only exercise its prosecutorial powers on a referral basis. Under the Securities Services Act, the competent courts further played a crucial role in the determination and calculation of the appropriate damages in civil cases of insider trading (s 77(1)(c)(i) to (iv); subs (2)(c)(i) to (v); (3)(b)(i) to (v) \& (4)(a) to (e)), namely the compensatory or punitive amounts to be paid to the FSB or to the actual prejudiced persons by the offenders. This enabled all the affected (claimants) persons to have an opportunity to get appropriate monetary remedies awarded to them by the courts from the FSB (s 77(7) to (10)). Likewise, the Financial Markets Act (s 82 read with s 83) extended the same role of the competent courts in respect of insider trading. Nonetheless, no appropriate presumptions were provided in the Securities Services Act (ss 73 \& 77) and the Financial Markets Act (ss 78 \& 82) to enable the Director of Public Prosecutions to obtain more convictions in criminal cases of insider trading and related offences. (See Loubser "Insider Trading and other Market Abuses including the Effective Management of Price-sensitive Information" (02-10-2006) 26-28 <http://www.jse.co.za/public/insider /JSEbooklet.pdf> (accessed 22-06-2013). Consequently, relatively few convictions and settlements have been obtained in cases involving insider trading by the courts and the FSB to date. (Only 32 cases of insider trading and eight cases of trade-based market manipulation were reportedly investigated by the FSB during the period between January 1999 and January 2008. However, no convictions were obtained by the courts in all these criminal cases. This information was obtained from an interview that was conducted at the FSB by the author, with Mr Gerhard van Deventer on 05 May 2009; see further the Directorate of Market Abuse Report Media Release <http://www.fsb.co.za> (accessed 13-06-2013)).

\subsubsection{The Role of the Ontario Securities Commission}

The OSC was established in 1966 as an administrative agency empowered to oversee securities trading and to provide 
public scrutiny of the investment market place, in order to combat illicit practices such as insider trading. (See Welling (1991) 363; Welling (2006) 1-728; Mann \& Lustgarten "Internationalization of Insider Trading Enforcement-A Guide to Regulation and Co-operation" in Hopt \& Wymeersch (eds) European Insider Dealing-Law and Practice (1991) 368). It has several powers which, inter alia, include powers to cease trade orders, issue compliance orders, and impose punitive and administrative penalties in civil cases of insider trading. (See Ziegel Studies in Canadian Company Law Volume 2: Corporation and Securities Law in the Seventies (1973) 444-449; International Claim Brokers v Kinsey (1966) 57 DLR (2d) 357)). Similar powers and functions are currently vested in the FSB in South Africa (s 84 of the Financial Markets Act).

\subsection{Overall Synopsis and Evaluation of the Anti-Insider Trading Regulatory and Enforcement Framework}

Canada employs a unique multi-functional regulatory model that does not empower any specific regulatory body to oversee the regulation of its securities and capital markets and/or the enforcement of the insider trading prohibition at a federal level (Thompson 9 \& related remarks under par 2 above). This suggests that in Canada the enforcement of insider trading laws is a shared responsibility involving the federal government, provincial governments and many other securities regulators such as the OSC, the Integrated Market Enforcement Teams (the IMETS), self-regulatory organisations, the Intelligent Market Monitoring System (the IMM), the Canadian Investor Relations Institute (the CIRI), the CSA and the Canadian Institute of Chartered Accountants (the CICA).

The OSC has, in some instances, managed to impose administrative penalties ranging from $\$ 100000.00$ to $\$ 1$ million on individuals and $\$ 500000.00$ to $\$ 5$ million on juristic persons (see Thompson op cit at 9). Moreover, the OSC introduced the OSC Policy 33-601 in 1998 to give guidelines relating to employee education, containment of inside information, compliance and restriction of transactions in order to curb insider trading. Accordingly, employee education involves awareness measures on insider trading and the prohibition thereof, ethical standards and consequences for violating the insider trading provisions. Containment (protection) of inside information involves limiting unauthorised transmission by restricting access to inside information, keeping information in sensitive areas secure and ensuring that electronic transmission of such information takes place under adequate supervision and control. Restriction of transactions involves the use of grey lists, restricted lists and information barriers. Lastly, compliance includes the monitoring and reviewing of trading in the OSC registrants' accounts, monitoring and restricting trade in securities about which the registrant or its employees may possess inside information, requiring all employees to maintain accounts with the employer registrant only, and conducting a periodic review of the adequacy of policies and procedures. (See the ITTF Report 15-16; Anonymous "A Guide to What Constitutes Inside Information" <http://www.uilo.ubc.ca> (accessed 22-042013).

The OSC also requires reporting issuers to report insiders in relation to them within ten days to curb insider trading, (see s 107(1); the OSC Rule 55-501 of 1996, 19 OSCB 821; the OSC "A Guide to Insider Reporting" May 1999 <http://www.osc.gov.on.ca> (accessed 22-05-2012) \& J Bewsey et al The Law of Investor Protection 2 ed (2003) at 287295). In relation to this, a System for Electronic Disclosure by Insiders (the SEDI) was adopted in 2001 to simplify the reporting and filing process of all insiders of the reporting issuers. (National Instrument 55-102 of 2001, 24 OSCB 4414 $<$ http://www.sedi.ca> (accessed 15-01-2013). Furthermore, section 135 of the Ontario Securities Act 1990 provides a method by which the OSC, security holders of a reporting issuer or security holders of a mutual fund may, in terms of section 134(3) or (4), institute an action in the name of the issuer or the mutual fund against the offenders. This has enabled the OSC to successfully investigate about eleven cases of insider trading during the period between 1995 and 2005 (Bhattacharya Enforcement and its Impact on Cost of Equity and Liquidity of the Market Report (2006) 155-156). Notwithstanding these efforts, it is submitted that the OSC has somewhat failed to consistently and successfully obtain more convictions in criminal cases of insider trading (see Thompson 17) to date. This could have been, inter alia, aggravated by the OSC's failure to employ other enforcement measures such as whistle-blowing immunity, bounty rewards and the fact that its biggest investigation unit within its enforcement department was under-staffed and it only had fourteen individuals as of late 2010. (See Janet McFarland "On the hunt for Illegal Insider Trading" The Globe and Mail 25 February 2011 <http://www.theglobeandmail.com/globe-investor/on-the-hunt-for-illegal-insider-trading/article 1915227/> (accessed 23-06-2013). However, this position is set to change as the OSC has, towards the end of 2010, successfully launched its own new in-house detection platform to crackdown insider trading and tipping offenders. Moreover, a new OSC chairman who was hired in 2011 pledged to expand the OSC's co-operation policy to encourage more people to settle with the OSC (bounty rewards) and to seek more resources in order to improve the enforcement of the insider trading ban. (Janet McFarland "New OSC Chief Pledges more Jail Terms for Securities Offenders" The Globe 
and Mail 9 March 2011 <http://www.theglobeandmail.com/report-on-business/new-osc-chief-pledges-more-jail-terms-forsecurities-offenders/article1830621/> (accessed 23-06-2013).

Apart from the OSC, the federal government as part of its efforts to strengthen the enforcement of the provisions against illegal insider trading and related practices, created the IMETS in Toronto, Montreal, Vancouver and Calgary to investigate capital markets fraud and insider trading cases. An effective process within the IMETS structure to address unlawful insider trading incorporates the activities of securities commissions, self-regulatory organisations, the Department of Justice and police officers who are highly qualified financial investigators. (See Anonymous "Federal Strategy to Deter Serious Capital Market Fraud" June 2003 <http://www.justice.ca/en/new/nr/2003doc30928.html> (accessed 18-11-2012). The IMETS have also developed some case assessment criteria and integrated procedures for the speedy prosecution of insider trading cases (See the ITTF Report 44 \& Ashe Insider Dealing (1992) 38-44).

Likewise, self-regulatory organisations such as the Market Regulation Services Incorporated, the Bourse de Montreal Incorporated ("an exchange that specialises in options"), the CIRI, the CICA, the CSA, the IMM and the ITTF have to date contributed immensely towards the combating of insider trading and related practices in Canada. (See the ITTF Report 23-29).

Furthermore, the courts have played a pivotal role in the enforcement of the insider trading prohibition in Canada as evidenced in some reported cases such as (Doman v British Columbia (Superintendent of Brokers) 2378), which involved approximately $\$ 2.3$ million in losses avoided, pursuant to a sale of Doman Industries Limited shares in 1988, $(R$ $v$ Harper 3664), which involved approximately $\$ 3.6$ million in losses avoided from the selling of shares of Golden Rule Resources Limited in 1997 and the (In the Matter of MCJC Holdings Inc and Michael Cowpland 1133), involving the sale of \$20.4 million in Corel Corporation shares also in 1997. (See related comments in pars 2.3 \& 2.5.3 above).

The Canadian multi-functional regulatory model is not employed in South Africa to combat insider trading. Instead, the regulatory powers and functions are specifically and mainly vested in the FSB to oversee the enforcement of insider trading ban in South Africa at a national level (s 84 of the Financial Markets Act). In relation to this, it is submitted that policy makers should, perhaps, consider enacting some additional provincial anti-insider trading by-laws to increase awareness and enhance the prevention of insider trading activities in South Africa (see related comments in par 2 above).

Both Canada and South Africa do not statutorily and expressly define the concept of "insider trading", (see par 2.1 above). Be that as it may, it is hoped that the South African policy makers will consider enacting adequate definitions of this concept and other related terms in order to consistently discourage illicit insider trading activities in the South African financial markets. Moreover, like all its predecessors, the Financial Markets Act's insider trading prohibition is still mainly applicable to securities listed on a regulated market (not necessarily including over the counter financial markets) and rigidly based on the requirement of knowledge before the offenders could incur any liability for insider trading offences (see related remarks in par 2.2 above). It is, therefore, submitted that the Financial Markets Act should be amended to incorporate provisions that streamline the requirement of knowledge on the part of the offenders to enhance the prosecution of insider trading cases in South Africa.

Notwithstanding the fact that relatively insufficient penalties are provided to combat insider trading in both Canada and South Africa (see par 2.3 above), it is submitted that the Financial Markets Act should be amended to enact specific provisions for separate and distinct maximum criminal and/or administrative penalties that can be imposed upon any juristic persons or individuals that commit or attempt to commit insider trading or other related offences in South Africa, with much higher maximum criminal or administrative penalties being imposed on such juristic persons to increase deterrence and enhance the combating of insider trading practices in the South African financial markets. Moreover, it is submitted that the Financial Markets Act should be amended to enact provisions for additional exemptions, Chinese walls and/or other defences for companies and individuals facing any charges of insider trading committed in South Africa or elsewhere (also see par 2.4 above).

It is further hoped that the South African regulatory bodies such as the JSE and the FSB will consistently participate, as is the position in Canada (see par 2.5.1 above), in the ISG and/or similar international initiatives in order to enhance the combating of cross-border insider trading activities in South Africa or elsewhere. Moreover, it is submitted that the policy makers should consider establishing, apart from the FSB, an additional independent regulatory body that will, from time to time, evaluate the adequacy (as well as the enforcement) of the relevant insider trading legislation and the role of the FSB and/or the JSE and make recommendations that could be employed to enhance the combating of insider trading activity in South Africa (also see par 2.5.2 above). Likewise, the Financial Markets Act should be amended to enact provisions for other enforcement methods such as whistle-blowing immunity, bounty rewards, private rights of action, additional self-regulatory organs and some presumptions that could be utilised by the FSB or the courts to enable 
them to obtain more convictions in criminal cases of insider trading (also see par 2.5 .3 above). Additionally, notwithstanding the challenges regarding the availability of sufficient resources, it is submitted that specialist courts or mediation, arbitration and settlement tribunals for insider trading and other related market abuse cases should be introduced on a regional basis or at least in each centre where there is a division of the High Court of South Africa to promote the timeous prosecution and settlement of such cases.

\section{Concluding Remarks}

As indicated above, it is clear that the insider trading legislation in both Canada and South Africa were constantly reviewed in a bid to address some of the flaws which were embedded in their provisions. However, it was noted that a relatively well developed and unique multi-functional regulatory model and anti-insider trading enforcement framework is in place in Canada (see pars 1; 2; 2.5 .3 \& 2.6 above). It was further noted, on the contrary, that no such model is employed in South Africa (see pars 1; 2; 2.5 .3 \& 2.6 above). Moreover, it was revealed that although the Canadian multifunctional regulatory model and anti-insider trading regulatory framework is not always uniform, it is has relatively managed to obtain more settlements and convictions in insider trading cases to date (see par 2.6 above). On the other hand, the article has revealed that relatively few insider trading cases were successfully settled or prosecuted in South Africa to date. In relation to this, the article also noted that certain flaws of the previous insider trading laws were recycled and re-incorporated into the Financial Markets Act. Given this background, it is hoped that the recommendations as enumerated in this article will be utilised by the relevant stakeholders in the future to improve the combating of insider trading in South Africa.

\section{References}

\section{Books}

Ashe M Insider Dealing (The Round Hall Press Dublin 1992)

Benade ML et al Entrepreneurial Law $3^{\text {rd }}$ ed (Lexis Nexis Butterworths Durban 2003)

Beuthin RC \& Luiz SM Beuthin's Basic Company Law $3^{\text {rd }}$ ed (Butterworths Durban 2000)

Bewsey J et al The Law of Investor Protection $2^{\text {nd }}$ ed (Sweet \& Maxwell Limited London 2003)

Condon MG et al Securities Law in Canada-Cases and Commentary $4^{\text {th }}$ ed (Emond Montgomery Publications Toronto 2006)

Mann MD \& Lustgarten LA "Internationalization of Insider Trading Enforcement-A Guide to Regulation and Co-operation" in Hopt KJ \&

Wymeersch E (eds) European Insider Dealing - Law and Practice (Butterworths London 1991)

Johnston D \& Rockwell KD Canadian Securities Regulation $4^{\text {th }}$ ed (LexisNexis Toronto 2006)

Macintosh JG \& Christopher NC Essentials of Canadian Law: Securities Law (Irwin Law Inc Toronto 2002)

Milne A et al Henochsberg on the Companies Act 3rd ed (Butterworths Durban 1975)

Rider BAK Insider Trading (Jordan \& Sons Limited Bristol 1983)

Welling B Corporate Law in Canada: The Governing Principles $2^{\text {nd }}$ ed (Butterworths Canada Ltd Toronto 1991)

Welling B Corporate Law in Canada: The Governing Principles $33^{\text {rd }}$ ed (Scribblers Publishing Ontario 2006)

Williamson JP Securities Regulation in Canada (University of Toronto Press Toronto 1960)

Ziegel JS (ed) Studies in Canadian Company Law Volume 2: Corporation and Securities Law in the Seventies (Butterworths Toronto 1973)

\section{Journal articles}

Bhana N "Take-Over Announcements and Insider Trading Activity on the Johannesburg Stock Exchange" 1987 South African Journal of Business Management 198-208

Botha D "Control of Insider Trading in South Africa: A Comparative Analysis" 1991 SA Merc LJ 1-18

Botha D "Increased Maximum Fine for Insider Trading: A Realistic and Effective Deterrent?" 1990 SALJ 504-508

Cassim "An Analysis of Market Manipulation under the Securities Services Act 36 of 2004 (Part 2)" 2008 SA Merc LJ 177-199

Henning JJ \& Du Toit S "The Regulation of False Trading, Market Manipulation and Insider Trading" 2000 Journal for Juridical Science 155-165

Jooste R "A critique of the insider trading provisions of the 2004 Securities Services Act" 2006 SALJ 437-460

Jooste R "Insider Trading: A New Clamp-Down" 1991 BML 248-250

Jooste R "Insider Dealing in South Africa-The Criminal Aspects" 1990 De Ratione 21-28

Luiz SM "Market Abuse II-Prohibited Trading Practices and Enforcement" 2002 Juta's Business Law 180-183

Luiz SM "Prohibition Against Trading on Inside Information-The Saga Continues" 1990 SA Merc LJ 328-332 
Luiz SM "Insider Trading Regulation - If at First You Don't Succeed..." 1999 SA Merc LJ 136-151

Luiz SM "Market Abuse and the Enforcement Committee" 2011 SA Merc LJ 151-172

Ojah K, Muhanji S \& Myburg A "Market Reaction and Equity Market Efficiency: A Survey of the Insider Trading Law in South Africa" 2008 The African Finance Journal 1-28

Osode PC "The new South African Insider Trading Act: Sound law reform or legislative overkill?" 2000 Journal of African Law 239-263

Osode PC "The Regulation of Insider Trading in South Africa: A Public Choice Perspective" 1999 African Journal of International and Comparative Law 688-708

Osode PC "The Regulation of Insider Trading in Canada: A Critical Appraisal" 1999 Anglo- American Law Review 166-196

Osode PC "Regulatory Theory, Private Interests and the Rationality of Insider Trading Regulation in the United States and Canada" 1998 Journal of South African Law 427-449

Thompson JH "A Global Comparison of Insider Trading Regulations" 2013 International Journal of Accounting and Financial Reporting $1-18$

Van der Lingen B "Tougher Legislation to Combat Insider Trading" 1997 FSB Bulletin 10

Van Deventer G "New watchdog for insider trading" 1999 FSB Bulletin 2-3

Van Zyl FH "Aspekte van Beleggersbeskerming in die Suid-Afrikaanse Reg" 1992 Transactions of the Center for Business Law 231-357

\section{Case law}

South Africa

Pretorius and Another v Natal South Sea Investment Trust 19653 SA 410 (W)

\section{Canada}

Doman v British Columbia (Superintendent of Brokers) (1998) BCJ 2378 (CA)

Green v Charterhouse Group Canada Ltd (1976) 12 OR (2d) 280 (CA)

In Re Harold P Connor (1976) OSC Bulletin 149

In the Matter of MCJC Holdings Inc and Michael Cowpland (2002) 25 OSCB 1133

International Claim Brokers v Kinsey (1966) 57 DLR (2d)

Lewis v Fingold (1999) 22 OSCB 2811

Multiple Access Ltd v McCutcheon and others (1982) 138 DLR (3d) 18 (SCC)

Re Cartaway Resources Corporation [2004] 1 SCR 672

Re Costello [2004] OJ 2972

Re Donald (2012) 35 OSCB 7383

Re Donnini [2003] OJ No 3541

Re Donnini (2003) 177 OAC 59 (Div Ct)

Re Donnini (2003) 37 BLR (3d) 46

Re Donnini (2002) 25 OSCB 4697

Re Donnini (28 January 2005) Doc. C41330 (Ont.C.A.)

R v Harper (2000) OJ 3664

Transpacific Sales Ltd (Trustee for) v Sprott Securities Ltd (2001) OJ 597(Sup Ct)

\section{Legislation}

\section{South Africa}

Companies Act 71 of 2008

Companies Act 61 of 1973

Companies Amendment Act 78 of 1989

Financial Markets Act 19 of 2012

Insider Trading Act 135 of 1998

Second Companies Amendment Act 69 of 1990

Securities Services Act 36 of 2004

\section{Canada}

Canada Corporations Act of 1970

Canada Business Corporations Act of 1975 Canada c 33 
Canada Business Corporations Act of 1985 RSC, C.C-44

Ontario Securities Act of 1966 c 142

Ontario Business Corporations Act of 1982 SO 1982 c 4

Ontario Securities Act of 1990 Revised Statutes of Ontario 1990 c S 5

\section{United States of America}

Securities Exchange Act of 1934 Public Law 73-291, 48 Stat 88115 USC 78a-78II

Bills

\section{South Africa}

Explanatory Memorandum to the Objects of the Companies Second Amendment Bill of 1990 B 119-90 (GA)

Financial Markets Bill B-2011

Financial Markets Bill B12-2012

Memorandum on the Objects of the Companies Second Amendment Bill of 1989 B 99-89 (GA)

Memorandum on the Objects of the Companies Second Amendment Bill of 1990 B 119-90 (GA)

\section{Canada}

Criminal Code of Canada 2004 c.3 S 5

Bill C-46

Bill C-13, 2004

\section{Dissertations}

Chitimira H The Regulation of Insider Trading in South Africa: A Roadmap for an Effective, Competitive and Adequate Regulatory Statutory Framework (LLM-dissertation University of Fort Hare 2008)

\section{Commissions, Reports and other Relevant Material}

\section{South Africa}

The King Task Group into Insider Trading Legislation Minority Report on Insider Trading 1997

The King Task Group into the Insider Trading Legislation First Report 15 May 1997

The King Task Group into the Insider Trading Legislation Final Report 21 October 1997

Van Wyk de Vries Commission of Inquiry into the Companies Act of 1973

\section{Canada}

Anonymous Ontario Securities Legislation 1977

Bhattacharya U Enforcement and its Impact on Cost of Equity and Liquidity of the Market Report 2006

National Instrument 51-102 "Continuous Disclosure Requirements" 27 OSCB 3443

National Policy 51-201 "Disclosure Standards" 25 OSCB 4497

National Instrument 55-102 of 2001, 24 OSCB 4414

OSC Policy 33-601 "Guidelines for Policies and Procedures Concerning Inside Information" 30 January 1998

The Report of the Attorney General's Committee on Securities Legislation in Ontario 11 March 1965

\section{Newspaper reports}

Chanetsa B "Insider Trading is Notoriously Hard to Prosecute" Business Report 26 April 2004

Emily Cole "Canada's first Criminal Conviction for Illegal Insider Trading" Criminal Law, Regulation and Enforcement Newsletter February 2010

Janet McFarland "On the hunt for Illegal Insider Trading" The Globe and Mail 25 February 2011

Janet McFarland "New OSC Chief Pledges more Jail Terms for Securities Offenders" The Globe and Mail 9 March 2011 


\section{Internet sources}

Insider Trading Task Force Report "Illegal Insider Trading in Canada: Recommendations on Prevention, Detection and Deterrence" (2003) <http://www.regulationservices.com/en/pdf/1TTFReport_20031112.pdf> (accessed 26-05-2013)

JSE Listing Requirements <http://www.jse.co.za> (accessed 13 October 2013)

Loubser R "Insider Trading and other Market Abuses (Including the Effective Management of Price-sensitive Information)" in the Insider Trading Booklet final draft (02-10-2006), <http://www.jse.co.za/public/insider/JSEbooklet.pdf> (accessed 22-06-2013)

Myburgh A \& Davis B "The Impact of South Africa's Insider Trading Regime: A Report for the Financial Services Board" (25-03-2004) $<$ http://www.genesis-analytics.com/public/FSBReport.pdf> (accessed 09-07-2013)

Smith M "Insider Trading" <http://www.parl.gc.ca> (accessed 22-12-2012)

Van Deventer G "Anti-Market Abuse Legislation in South Africa" (10-06-2008) <http://www.fsb.co.za/public/marketabuse /FSBReport.pdf> (accessed 05-08-2013) 